\title{
Enfrentamento Religioso e Política: As Lições da Resposta à Aids
}

\author{
Vera Silvia Facciolla Paiva ${ }^{\mathbf{1}}$ \\ Departamento de Psicologia Social e do Trabalho da Universidade de São Paulo, \\ São Paulo, Brasil \\ Andrea Paula Ferrara \\ Mafoane Odara Poli Santos \\ NEPAIDS - Instituto de Psicologia da Universidade de São Paulo, São Paulo, Brasil \\ Richard Parker \\ Department of Sociomedical Sciences of Columbia University, New York, USA
}

\section{Resumo}

O enfrentamento do adoecimento e a interação com diferentes religiosidades são desafios para a prática profissional, especialmente quando a sexualidade está envolvida. Que lições o enfrentamento religioso da Aids poderia oferecer? Baseado em pesquisa documental, estudos de caso, oficinas e entrevistas, este artigo discute o enfrentamento da Aids nas primeiras décadas de epidemia em São Paulo na perspectiva de religiosos. Lideranças de várias tradições religiosas co-construíram a resposta social à epidemia, incluindo a prevenção centrada no uso do preservativo. Noções de solidariedade, direitos humanos e ecumenismo expressavam a mobilização democrática pós-ditadura paralela à emergência da doença. "Católico-humanistas" no governo compartilhavam essa perspectiva com seus pares da hierarquia católica, estimulando um enfrentamento religioso de estilo "colaborativo". Doentes com Aids, inclusive padres e seminaristas, foram acolhidos com apoio da Arquidiocese, enquanto acirrado debate interno opunha pastoralistas e adeptos da teologia da libertação aos canonistas (vaticanistas) que, desde então, disseminaram um discurso de enfrentamento de "estilo delegante" e moralista, especialmente no campo da prevenção. Religiosos em qualquer posição (fiéis, clérigos, autoridades) produzem e reproduzem discursos implicados em estilos de enfrentamento religiosos disponíveis em seus contextos socioculturais e políticos; seus simbolismos permanecem no enfrentamento pessoal - com efeitos cognitivo-emocionais e comportamentais. $\mathrm{O}$ enfrentamento religioso não pode ser reduzido ao comportamento individual e à relação pessoal com o dogma, o sagrado e o transcendental. Uma compreensão mais ampla das suas dimensões psicossociais e político-institucionais, assim como a interação do discurso técnico com a religiosidade viva, enriquecerão a pesquisa e a prática profissional na promoção da saúde.

Palavras-chave: Enfrentamento, religião, Aids, instituições.

\footnotetext{
Endereço para correspondência: Departamento de Psicologia Social e do Trabalho, Instituto de Psicologia, Universidade de São Paulo, Av. Prof. Mello Moares, 1721, Cidade Universitária, São Paulo, SP, Brasil 05508900.E-mail: veroca@usp.br, apferrara@uol.com.br,mafoane@gmail.com ergp11@columbia.edu Agências de Financiamento: National Institutes of Health (NIH) /USA, Mac Arthur Foundation e Conselho Nacional de Desenvolvimento Cientifico e Tecnológico (CNPq).
} 


\title{
Religious Coping and Politics: Lessons from the Response to Aids
}

\begin{abstract}
Religious coping with illness and the interactions among diverse forms of religiosity have posed challenges for the practice of health professionals, especially when sexuality is involved. What lessons can coping with AIDS offer? Based on archival research, case studies, workshops, and interviews, this article discusses the response to AIDS through the perspective of religious leaders who lived through its first decades in São Paulo, Brazil. Notions of solidarity, human rights, and ecumenicalism were articulated in the construction of the social response to the epidemic, including prevention efforts centered on condom use. These ideas expressed the historical period when mobilization for democracy post-dictatorship paralleled the AIDS crisis emergence. As in other religious traditions, "humanist-Catholics" in the government shared this perspective with their peers in the higher rungs of the Church, producing a "collaborative" religious coping style. In the Catholic responses, people with AIDS, including priests and seminarians, were cared for with the support from the Archdiocese, while the strained internal debate created opposition among "pastoralists" and followers of Liberation Theology and "canonists", especially in the field of prevention in which the Vatican delivered a discourse of a moral and "delegating" style of coping. Religious followers in whatever position - followers, clergy, authorities - produce and reproduce discourses on religious coping available in their socio-cultural and political contexts; its symbolisms remain implicated in personal coping - with cognitive, emotional and behavioral effects. Religious coping cannot be reduced to individual behavior and its relationship with dogma, the sacred and the transcendental. A broader comprehension of its psychosocial and institutional-political dimensions, as well as the interaction with the lived religiosity will enhance the research and the professional practice.
\end{abstract}

Keywords: Coping, religion, Aids, institutions.

\section{Afrontamiento Religioso y Política: Las Lecciones de la Respuesta al Sida}

\section{Resumen}

Afrontamiento con la enfermedad y las interacciones entre diversas formas de religiosidad son desafíos para la práctica de los profesionales de la salud, sobre todo cuando se trata de la sexualidad. ¿Qué lecciones ofrece el afrontamiento con el SIDA? Basado en estudio documental, estudios de casos, talleres y entrevistas, este artículo discute la respuesta al SIDA a través de la perspectiva de los líderes religiosos que vivieron sus primeras décadas en São Paulo, Brasil. Las nociones de solidaridad, los derechos humanos y ecumenismo se articularon en la construcción de la respuesta social a la epidemia, incluyendo los esfuerzos de prevención centradas en el uso del condón. Estas ideas expresan el período histórico en el que la movilización de la democracia post-dictadura apareció paralelamente a la crisis del SIDA. Tal como en otras instituciones religiosas, "católico-humanistas", dentro y fuera del gobierno y de la jerarquía de la Iglesia, han producido un "estilo colaborativo" de afrontamiento religioso. En el campo católico, personas enfermas de SIDA, inclusive padres y seminaristas, fueron amparados con apoyo de la Arquidiócesis, mientras un intenso debate interno oponía a "pastorialistas" y adeptos a la teología de la liberación, a los "canonistas" y seguidores del Vaticano, especialmente en la prevención campo donde los "vaticanistas" diseminaban un discurso de afrontamiento moralista de estilo "delegante". Religiosos en cualquier posición - fieles, clérigos, autoridades - producen o reproducen discursos con estilos de afrontamiento religioso a la enfermedad disponibles en sus contextos socio-culturales e políticos; sus simbolismos permanecen implicados en el enfrentamiento personal - con repercusiones cognitivas, emocionales y de comportamiento. Estudios y prácticas profesionales en el campo del afrontamiento 
religioso se enriquecerían al considerar dimensiones que no pueden reducirse al comportamiento individual y a la relación con el dogma, lo sagrado y lo transcendental. Una comprensión más amplia de las dimensiones psicosociales, institucionales, y políticas, también la interacción con la religiosidad viva, enriquecerá la investigación y la práctica profesional.

Palabras clave: Afrontamiento, religión, SIDA, instituciones.

O crescimento de postos de trabalho no campo da saúde e da assistência social ampliou os territórios tradicionais para a atuação do psicólogo. ${ }^{2} \mathrm{Na}$ última década, novas práticas desenvolveram-se no campo da atenção básica em saúde e em contextos de alta complexidade hospitalar, renovaram-se os modelos psicoterápicos e de prevenção (Centro de Referência Técnica em Psicologia e Políticas Públicas [CREPOP], 2008, 2009; Perucchi, Rodrigues, Jardim, \& Calais, 2011; Sampaio \& Araújo, 2006; Zurba, 2011). Um dos desafios à atuação profissional neste contexto é a interação da religiosidade de pacientes e profissionais.

$\mathrm{Na}$ literatura acadêmica sobre religião e psicologia, duas ordens de questões são mais frequentes: como considerar ou lidar com a religiosidade dos pacientes no âmbito das práticas psicoterapêuticas e qual o papel do comportamento religioso como um fator no enfrentamento de contextos sociais de adoecimento (Faria \& Siedl, 2005; Peres, Simão, \& Noasello, 2007). A religiosidade de profissionais e de autoridades religiosas permanece rara como questão para pesquisa, embora as pessoas praticantes e com crenças mais fortes frequentemente demonstrem desconforto no encontro com as teorias psicológicas. ${ }^{3}$ Trata-se de uma lacuna importante no debate acadêmico e seria importante conhecer a dinâmica da religiosidade daqueles que constroem os discursos sociais e políticos

2 No Brasil, se dá no âmbito do Sistema Único de Saúde (SUS) e Sistema Único de Assistência Social (SUAS) organizados desde os anos $1988 \mathrm{e}$ 2005 no Brasil, respectivamente, como sistemas públicos que organizam, de forma descentralizada, os serviços de atenção, vigilância e prevenção à saúde (SUS) e os socioassistenciais (SUAS).

3 A religiosidade de psicólogos e a de seus pacientes tem sido descrita como uma das motivações para os alunos se aproximarem do tema "psicologia e religião" (G. J. Paiva et al., 2009). que coproduzem os sentidos do enfrentamento religioso como um fenômeno psicologicamente encarnado (Garcia, Muñoz-Laboy, Almeida, \& Parker, 2009).

No âmbito dos conselhos que fiscalizam e regulamentam o exercício profissional, por outro lado, a reflexão crítica e conceitual sobre a religiosidade dos psicólogos foi intensificada na última década, paralela ao aparecimento da epidemia da Aids e dos movimentos políticos e socioculturais de afirmação da identidade homossexual. A literatura acadêmica indica que a condenação religiosa da homossexualidade contribui para a produção do estigma e da discriminação de homossexuais que, por sua vez, tem sido associada à maior vulnerabilidade aos agravos de saúde mental e sexual em diferentes culturas (Garrido, Paiva, Nascimento, Souza, \& Santos, 2007; Gough, 2007; Govender, 2011; Kian \& Anderson, 2009; Parker \& Aggleton, 2001, 2003). No Brasil, a resolução do Conselho Federal de Psicologia (Resolução CFP n ${ }^{\circ}$ 01/99) expressou o debate desses dados no quadro dos direitos humanos, bastante documentada no campo da Aids, e coibiu as práticas dedicadas à cura da homossexualidade ou que contribuem para a discriminação de não-heterossexuais.

O campo da prevenção e cuidado em Aids tem lições a oferecer. A eficácia nesse campo dependeu da inovação técnica na interação entre diferentes religiosidades, exigiu respeito aos diferentes estilos de vida de usuários de serviços e interpelou práticas profissionais fortemente marcadas por valores pessoais. Seja na promoção do preservativo, no cuidado aos doentes, na atenção primária ou no setor de assistência social, a resposta profissional à epidemia estimulou nas últimas décadas a revisão de teorias e técnicas ensinadas nos cursos de graduação, especialmente no campo da sexualidade (Parker, Garcia, \& Muñoz-Laboy, 2013). Essas respostas também validaram a perspectiva dos direitos hu- 
manos em saúde (Gruskin \& Tarantolla, 2008, 2012; V. Paiva, 2008).

Desafios deste porte não estiveram restritos ao contexto brasileiro. Em panorama global sobre a epidemia entrando em sua segunda década, Mann e Tarantola (1996) incluíam a religião como um aspecto importante da vulnerabilidade social à Aids. Entendiam que, para grande parte das pessoas, a religião atribui sentido à vida - nascimento, casamento, sofrimento e morte. Religiosos atuam para normatizar a sexualidade, se envolvem na ação política e legislativa, em programas educacionais, em instituições médicas e constroem atitudes em relação às doenças. Os autores perguntavam, então: "os profissionais da saúde deveriam temer a intervenção religiosa" ou "considerar lideranças religiosas e sua moralidade como aliados no contexto da Aids"? (Mann \& Tarantola, 1996, p. 447). Como discutiu Defert (1996), programas em diversos países tratavam da sexualidade, do estigma, do uso de preservativo de modo secular e não encontraram uma resposta simples.

Se tomarmos o período do surgimento da Aids como exemplo, observaremos diferentes manifestações públicas de enfrentamento religioso dessa situação de crise desde o início dos anos 1980. Bastante conhecido é o esforço de organizações lideradas por autoridades e instituições religiosas para organizar a solidariedade e o cuidado de pessoas afetadas pela epidemia em todo mundo (Garcia \& Parker, 2011; Sanchez \& Nappo, 2008). Por outro lado, enquanto alguns religiosos, familiares e técnicos de várias áreas da saúde respondiam à necessidade de controlar a pandemia e mitigar o padecimento físico e mental dos doentes, diversas lideranças políticas e profissionais estimulavam o estigma e a discriminação associados ao HIV baseados em sua fé pessoal - do púlpito das igrejas, no serviço público e até na universidade (Farmer, 1999; Galvão, 1997; Garcia et al., 2009; V. Paiva \& Zucchi, 2012).

No Brasil, a epidemia da Aids e o movimento pela democratização cresceram no mesmo período histórico (Berkman, Garcia, Munoz-Laboy, Paiva, \& Parker, 2005). Em 1988, a Constituição brasileira passou a garantir a con- vivência social e a ação governamental referidas à liberdade religiosa e à laicidade do Estado, assim como incluiu o direito universal de acesso à saúde integral - da prevenção à reabilitação. Em duas décadas a política governamental de prevenção centrada no uso do preservativo conquistava enorme aprovação, apesar de a maioria dos brasileiros se declarar católica e o Vaticano ser contra ${ }^{4}$ (V. Paiva, Aranha, Bastos, \& Grupo de Estudos em População, Sexualidade e Aids [GEPSAIDS], 2008). Como interpretar esse contexto social, cultural e político e suas consequências psicológicas?

Cientistas sociais estudiosos das religiões no Brasil ressaltam que as dimensões pessoais e cotidianas devem ser consideradas na produção da história das religiões (Burdick, 1996; Chesnut, 1997). Tem-se descrito como na dinâmica da filiação religiosa o ethos privado e a ação individual do sujeito religioso são frequentemente interpelados pelo cotidiano (Duarte, 2005; Watanabe, 2005). Foi também esta dinâmica que produziu a polarização das reações ao surgimento da epidemia e contribuiu para o caminho resultante do conflito na direção que foi chamada de "resposta brasileira à Aids".

\section{Enfrentamento Religioso}

No campo da psicologia da religião, G. J. Paiva $(1998$, p. 28) chamou a atenção para a literatura sobre stress e enfrentamento dedicada às relações entre saúde e religião no contexto da Aids e destacou a obra de Pargament ${ }^{5}$ que definiu o enfrentamento como o processo de buscar entender e lidar com importantes exigências

Pesquisa nacional e domiciliar nacional observou que a educação sobre o uso de preservativos na escola para maiores de 15 anos era fortemente apoiada em todas as filiações religiosas - por 94,5\% dos petencostais, 98,5 dos católicos e $100 \%$ dos adeptos das religiões afro-brasileiras; observou ainda que $83 \%$ apoiava a facilitação do acesso de preservativos para adolescentes na escola e $94 \%$ nos postos de saúde (V. Paiva et al., 2008).

5 Pargament, K. I. (1990). God help me: Toward a theoretical framework of coping for the psychology of religion. Research in the Social Scientific Study of Religion, 2, 195-224. 
pessoais e situacionais, fenômeno psicossocial que o aparecimento da Aids mobilizou.

Foram os estudiosos do stress e de seu enfrentamento os primeiros pesquisadores em psicologia a se dedicar às pessoas afetadas pela Aids, antes da existência das terapias antirretrovirais (Coates, Temoshok, \& Mandel, 1984; Vasconcellos, 1992). Dentre os mais importantes aspectos para a avaliação de situações da qual o enfrentamento depende, está a atribuição de origem e causa, tanto do evento estressante como da reação a esse evento. A literatura sobre enfrentamento religioso de situações de stressque anotamos ser resultante principalmente de estudos sobre cristãos - é abundante em descrever como se atribui a Deus as causas de acontecimentos, particularmente negativos, e como as pessoas permanecem passivas e a Deus recorrem como o agente ativo.

Bastante sofisticada, a teoria do enfrentamento do stress dedica-se fundamentalmente ao contexto das doenças crônicas, como hoje se define a Aids onde há acesso ao tratamento com antiretrovirais. $\mathrm{O}$ processo de enfrentamento descrito na literatura indica repercussões no plano cognitivo, emocional e comportamental. Os autores deste campo teórico que estão mais fortemente posicionados na psicologia social reconhecem que o modo de enfrentamento é "influenciado pela cultura" que modela avaliações de situação e que o "sistema de orientação das pessoas no mundo e as estratégias de enfrentamento" podem ser "ensinadas e privilegiadas em um contexto sociocultural, em detrimento de outras" (Faria \& Seidl, 2005, p. 383). O modo de enfrentamento e as funções assumidas pela religião na resolução de problemas dependem do estilo de enfrentamento adotado pela pessoa, de como localiza a responsabilidade e do quanto participa. No estilo autodirigido de enfrentamento religioso ao evento estressante, a responsabilidade de enfrentar os problemas é localizada no individuo autônomo, sem referências transcendentais. No estilo delegante, deixa-se a solução para a esfera divina, frequentemente "nas mãos de Deus". No estilo colaborativo se recorre tanto à participação e responsabilidade individual como à divina (Faria \& Siedl, 2005; G. J. Paiva, 1998).
Este artigo abordará o enfrentamento religioso na perspectiva dos religiosos que participaram dos primeiros anos de construção da resposta social e psicossocial à Aids em São Paulo e em várias posições institucionais, em particular dos católicos. Descreveremos o modo como expressaram sua religiosidade no advento da epidemia enquanto interagiram com a resposta governamental à Aids que se organizava baseada em evidências produzidas pela epidemiologia, infectologia, e medicina preventiva, entre outras disciplinas.

Estaremos tratando dos religiosos mais que de seus fiéis, e adotamos a noção de religiosidade sintetizada por Faria e Siedl (2005), concebida como uma adesão primária a crenças e práticas de uma religião organizada, com aspectos pessoais e institucionais. Como veremos, essa história pode inspirar novas pesquisas e as práticas de intervenção psicossocial que interagem com a religiosidade - um fenômeno psicológico indissociável do seu contexto social, cultural e político.

\section{Método}

O material analisado neste estudo foi colhido no âmbito de projeto de pesquisa multicêntrica ${ }^{6}$ cujo objetivo mais geral era compreender como instituições de tradições religiosas cristãs e afro-brasileiras no Brasil concebiam a Aids e de que maneira se articularam para participar na resposta social e política à epidemia.

O caminho metodológico para a discussão que se segue foi planejado com base no modelo para pesquisa etnográfica de Burawoy (2009) conhecido como "extended case method", onde se combinam a observação direta e a análise his-

${ }^{6}$ Este artigo baseia-se em dados coletados na pesquisa "Religious Responses to HIV/AIDS in Brazil". A pesquisa nacional foi coordenada de 2005 a 2009 por Richard G. Parker e conduzida em 4 cidades: Rio de Janeiro (coordenada por Veriano Terto Jr.), Porto Alegre (coordenada por Fernando Seffner), Recife (coordenada por Felipe Rios) e São Paulo (coordenada por Vera Paiva). Informação adicional sobre o projeto pode ser obtida em http:www.abiaids.org.br, website da Associação Brasileira Interdiciplinar de Aids. 
tórica com base na observação sobre diversos momentos ao longo do tempo, análise que permite também compreender como forças políticas e estruturais se combinam. A pré-análise de documentos (por exemplo, mídia disponível, relatórios de governo, das organizações estudadas e a literatura acadêmica) foram fundamentais para a seleção de informantes-chaves entrevistados no processo de investigação.

No caso aqui analisado - a resposta religiosa à Aids em São Paulo nas primeiras duas décadas - a primeira atividade de pesquisa foi uma entrevista em grupo no formato de uma oficina de debates com lideranças religiosas das três matrizes religiosas focalizadas - Católica, Umbanda-Candomblé, Protestantes-evangélicos - somados a profissionais de saúde ligados a programas de Aids e que participaram de vários momentos da resposta religiosa - psicólogos, médicos e assistentes sociais. Uma "linha do tempo" produzida coletivamente foi o principal resultado dos debates sobre essa história na cidade. ${ }^{7}$ Iniciada na parte da manhã com grupos separados por matriz religiosa, na parte da tarde uma sala reuniu o grupo inter-religioso para construir uma única narrativa e refletir criticamente sobre ela.

A descrição e análise neste artigo estará também baseada no conteúdo de 78 entrevistas em profundidade realizadas a seguir, de 2005 a $2008 .^{8}$ Todos os entrevistados - pais e mães de santo, pastores, padres, capelão, membros de organizações sociais religiosas, ativistas da Pastoral de DST/Aids, catequistas e profissionais de programas de Aids - estiveram diretamente envolvidos com a resposta governamental e não governamental nos primeiros anos da epidemia em São Paulo. Foram significativos para essa análise os dados colhidos em estudo de caso sobre uma Organização Não Governamentais (ONG) fundada nos anos 1980, onde se conduziu pesquisa documental e entrevistou coordenadores, funcionários e usuários.

O resultado desta atividade está publicado em Souza, Santos, Almeida e Paiva (2012).

8 Do total de entrevistas, 8 foram especificamente colhidas como histórias de vida, 13 no formato de história oral e 15 como depoimentos de informantes-chaves.
As lideranças históricas entrevistadas, algumas já idosas no momento da entrevista, também forneceram documentos históricos que apoiaram o caminho da análise. Entre os documentos examinados, para este texto ressaltamos as atas do Grupo de Trabalho Aids e Religiões junto ao Programa Estadual de DST/Aids do Estado de São Paulo e documentos acessados em pesquisa conduzida nos Arquivos da Cúria Metropolitana e Biblioteca da Conferência Nacional dos Bispos do Brasil (CNBB) em São Paulo.

Todos os entrevistados e participantes de atividades em grupo assinaram um termo de consentimento, livre e esclarecido antes das entrevistas, que foram gravadas e transcritas. $\mathrm{O}$ projeto foi aprovado pela Comissão Nacional de Ética em Pesquisa (CONEP) do Ministério da Saúde.

A análise terá como referência o quadro das abordagens psicossociais em saúde, na vertente construcionista baseadas nos direitos humanos (V. Paiva, 2012a, 2012b). Validadas e globalizadas no contexto da resposta global à Aids (Gruskin \& Tarantola, 2008, 2012) e integrada às concepções da compreensão do processo saúde doença no quadro da vulnerabilidade (individual, social e programática). Essa perspectiva baseada nos direitos humanos enfatiza que não há uma "história natural da doença" senão uma "história social da doença", não apenas porque é impossível pensar o processo saúde-doença independente de seus determinantes socioculturais, históricos e estruturais, mas porque " $\mathrm{so}$ cial e histórica é também a forma de contá-la" (Ayres, Paiva, \& França, 2010, 2012).

Ao revisitar a história social da Aids com base nos depoimentos de religiosos analisados nesse quadro conceitual, este texto pretende ampliar a compreensão do enfrentamento religioso que não será, portanto, discutido apenas do ponto de vista do comportamento individual.

\section{O Contexto da Resposta aos Primeiros Casos de Aids em São Paulo}

Todos os anos eles preparam uma liturgia para rezar pelas vitimas da Aids. O que adianta? Eles já estão com Deus, não pre- 
cisam mais da tua oração... No começo, nós tínhamos em São Paulo o Dom Paulo [Arcebispo] e ele era a favor do preservativo, com a teoria de que "entre os males, o menor". Sustentado por muitos religiosos, muitos bispos, padres. Eu pessoalmente sempre dizia: se é para prevenir, preservar a vida, então não é um mal maior, mas é um bem maior. Devemos sempre olhar a defesa da vida e fazer de tudo para defendê-la, usar todos os meios que a nossa inteligência alcança para poder fazer que a nossa vida seja vivida na plenitude. Esse é o pensamento de Cristo, o pensamento do evangeIho. "Eu vim para que todos tenham vida, e tenham plenitude". (Padre, entrevistado em 2006)

Alguns fatores contribuíram para que o estado de São Paulo respondesse rapidamente à epidemia e organizasse o primeiro programa de Aids das Américas em 1983. A cidade de São Paulo, além de centro de negócios e polo industrial do país, sediava uma sinergia de movimentos sociais de resistência à ditadura desde os anos 1970: movimentos estudantis por liberdades democráticas, movimentos sindicais pela dignidade no trabalho ${ }^{9}$ além do nascente movimento homossexual e dos movimentos de mulheres contra a pobreza, em coalizão com o feminista.

Contemporânea ao registro dos primeiros casos de Aids, a chamada "distensão política" conduzida pelo governo militar permitiu, depois de duas décadas, a eleição pelo voto popular de governos locais. O governador eleito em 1982, Franco Montoro, era professor de filosofia e, originário do movimento "humanista cristão", contrastava com governantes católicos e conservadores indicados pelos militares em toda América Latina. Os humanistas defendiam a "dignidade da pessoa humana" em diversos movimentos sociais. Ao assumir o governo, faziam frequentes referências à Declaração dos Direitos Humanos de 1948, à "ética da solidariedade", ao princípio da "participação" e à promoção da cidadania "que não é apenas direito, mas tomada de cons-

Liderados por Lula da Silva - operário que foi presidente do Brasil de 2002-2010. ciência e responsabilidade social" (Pollozi \& Souza, 2001, p. 13).

Esse governo estadual acolheu, então, uma resposta quase imediata aos primeiros casos notificados em 1981-82 e os profissionais que o fizeram, originários do movimento pela reforma sanitária desde os anos 1970 e que agora atuavam como servidores públicos na secretaria da saúde e nos municípios paulistas mais afetados, defendiam o direito universal à saúde. Pelo menos um ano antes da articulação do Programa Nacional de Aids, esse cenário político produziu a primeira organização não governamental brasileira dedicada às pessoas afetadas pela epidemia (Grupo de Apoio a Prevenção à Aids [GAPA]) organizada também por profissionais da secretaria estadual da saúde de São Paulo e por lideranças do movimento homossexual e de direitos humanos.

Os depoimentos de informantes chaves que participaram desse momento indicaram que, desde logo, muitos religiosos buscavam informações reagindo aos casos de Aids nas suas igrejas, nos seus terreiros ou nos seus centros espíritas. Esses religiosos optavam pela não exclusão dos portadores do HIV em sua comunidade e procuravam profissionais de saúde com o objetivo de atuar informados pelo discurso técnico-científico. Boa parte dessas lideranças religiosas tinha uma história anterior de atuação em trabalhos sociais: eram católicos provenientes dos Movimentos Eclesiais de Base por justiça social e saúde, protestantes ligados ao Movimento Ecumênico $^{10} \mathrm{e}$ à luta pelos Direitos Humanos, adeptos de religiões afro-brasileiras que lutavam contra a intolerância religiosa e a favor da cultura da paz.

Já em 1985, com apoio do Programa Estadual de DST/Aids de São Paulo, os religiosos de matrizes afro-brasileiras produziram um manual de como manipular navalhas e tesouras de modo seguro, preocupados em garantir a não-extinção de seus rituais, resistindo a acusação de disseminar "coisas ruins... desta vez, de espalhar o vírus

10 Para uma discussão do papel da Igreja Católica na defesa dos direitos humanos, sobre suas comunidades eclesiais de base e a teologia da libertação ver Azevedo (2004) e Burdick (1996). 
da Aids". Em 1986, organizou-se o Grupo Especial de Cultura, Candomblé e Aids (GECAIDS) quando já se contavam dezenas de sacerdotes desta tradição religiosa entre os doentes que morriam de Aids.

No meio protestante e evangélico, pessoas com histórico de luta pela democracia e por justiça social tentavam incluir a questão da Aids no quadro das lutas focalizadas na "superação da pobreza e da exclusão de classe" que apoiavam. Os entrevistados relataram, entretanto, a dificuldade de colocar a questão da Aids na agenda do Conselho Mundial de Igrejas de modo significativo até 1995 , porque muitas pessoas atingidas pela epidemia não se enquadravam nessas clássicas definições de exclusão.

São Paulo tem sido o estado brasileiro mais afetado pela epidemia e tinha como capital social e político muitas lideranças da luta democrática e possibilidade de inovar informado pelo pensamento técnico-científico de programas de saúde e universidades. No campo católico o arcebispo de São Paulo, D. Paulo Evaristo Arns, foi citado unanimemente como um apoio importante. Nomeado Cardeal nos anos mais duros da ditadura, acolhia os adeptos da "teologia da libertação" (TL) que lutavam pelo fim das torturas e restabelecimento da democracia (Gaspari, 2002). Essa não era a atitude de toda a Igreja Católica brasileira que polarizava a resposta à Aids (Galvão, 1997; Parker \& Aggleton, 2003). Como discutiu Mott (1985), num extremo situava-se o Cardeal do Rio de Janeiro, D. Eugênio Sales, intransigente, acusador dos doentes e moralizador, no outro, "mais magnânimo o Cardeal de São Paulo" que ressaltava a missão de reconfortar os doentes de Aids, como todos os doentes graves.

$\mathrm{O}$ acolhimento aos doentes, estimulado pelos técnicos da saúde, foi realizado desde logo nos terreiros de matriz afro-brasileira, mais abertos aos homossexuais bastante atingidos pela epidemia. Ecoava o contexto de resistência democrática e a resposta não governamental e, não sem dificuldades e oposição, o governo forneceu recursos técnicos e financeiros. Como recordou um médico que participou ativamente da construção deste primeiro programa no Brasil, foi possível buscar o respeito aos direitos humanos e a solidariedade na atenção dedicada ao adoecer e morrer com dignidade. Os profissionais de saúde, incluindo muitos psicólogos que trabalhavam neste Programa de Aids, souberam valorizar o humanismo dos católicos, no governo e articulados na capilaridade da Arquidiocese. Com base na noção de "ecumenismo" e "solidariedade" religiosos, atividades de atenção e prevenção que ajudaram a diminuir o estigma associado à doença foram co-organizadas.

O primeiro ano em que se organizou o Dia Mundial da Aids. Tivemos uma cerimônia ecumênica na Catedral, com Dom Paulo e com outras autoridades religiosas, do Candomblé, e com o rabino dos judeus, que se envolveu muito precocemente também. (Médico sanitarista)

Profissionais de saúde entrevistados lembraram como os grupos católicos, evangélicos e protestantes que compartilhavam a inspiração da teologia da libertação, caminharam em São Paulo "muito rápido para uma redução de estigma e discriminação e uma atitude mais progressista". $\mathrm{O}$ mesmo observavam entre lideranças religiosas de diversos grupos espíritas e judeus, sacerdotes da Umbanda e do Candomblé chamados a participar.

A assistência e apoio aos doentes de Aids, ainda sem tratamento disponível, era o foco dos religiosos nessa primeira década da epidemia. $\mathrm{O}$ tema era tratado com discrição, cercado de segredo, mas não se negava o que acontecia. Segundo depoimento de um padre, idoso no momento da entrevista, ao espanto com os primeiros casos de sacerdotes e seminaristas internados com Aids em meados dos anos 1980, seguiu-se o cuidado e solidariedade:

Era 1988... Uma senhora, idosa, 72 ou 73 anos, numa reunião de agentes da Pastoral se expressava à respeito da Aids: "Padre, aquela doença que dá em padre...?" [risos] . .. O que eu quero marcar fortemente é uma situação de confusão. Não se compreendia bem a doença, tinha-se um medo enorme, porque as pessoas morriam em pouco tempo, então as pessoas ficavam numa reserva muito grande... Uma atitude humana, cristã, é a solidariedade. Essa se impôs, viu? 
Graças a Deus, nós não temos mais essas restrições. Como se diz, a reprovação de certos comportamentos da moral católica não tira a dignidade da pessoa. (Padre que participava da Pastoral da Saúde)

A solidariedade era, de todo modo, quase sempre regulada pela normatividade das comunidades religiosas que a sustentavam. Algum tipo de adequação aos princípios religiosos da congregação, igreja, templo ou terreiro era condição para que se oferecesse apoio e cuidado. Era comum, por exemplo, a exigência de regras de silêncio e da reclusão de membros daquela comunidade religiosa - caso especialmente visível em relação aos religiosos católicos vivendo com HIV, e bem menos comum entre os adeptos da Umbanda/Candomblé, segundo os entrevistados.

Outro entrevistado, que foi pároco por nove anos, narrou seu primeiro contato com o adoecimento e "a morte de dois companheiros" em meados dos anos 1980. O primeiro era seminarista que, quando desenvolveu Aids, conseguiu resistir sem pedir ajuda, trancado no quarto. Contou como foi chocante vê-lo pela última vez quando saiu para ser internado. Sem contato ou informação, depois soube que ele morreu. O "morreu de quê ficava para o grupo seleto de pessoas amigas... tudo era desajeitado na época e sem muito sentimento de solidariedade". O entrevistado definiu o segundo caso como um suicídio, "uma saída" para a situação. "Ele atravessou de qualquer jeito a avenida movimentada, foi levado com vida para o hospital. Um padre que morava com ele relatou que ouviu dois médicos comentando que ele tinha Aids".

Entrevistados de todas as matrizes religiosas concordaram que a opção pelo segredo devia-se, em primeiro lugar, à insegurança sobre os modos de transmissão, para evitar o pânico caso se soubesse que acolhiam doentes com Aids. A associação da epidemia com promiscuidade e uma "peste gay" também indicava a reserva. Como lembra outro sacerdote:

Diante da insegurança, poucas pessoas se dispunham a acolher, a acompanhar esses portadores do vírus. Neste ponto Dom Paulo teve grande influência psicológica: nós não podemos deixar de cuidar de pessoas e não é porque nós não aprovamos a homossexualidade que nós vamos deixar de tratar essas pessoas.

Os entrevistados também concordaram que a maior parte dos que logo se envolveram no esforço contra a Aids estavam mobilizados pela história de um conhecido afetado pela doença. A mobilização institucional ocorreu gradativamente e estimulada pela noção de "solidariedade" e "compaixão". Tanto as narrativas como os documentos analisados traçam paralelos entre as atividades do sacerdócio com a de "cuidador de almas", "pastor" e a noção de "acolhimento" dos que sofriam. Nos primeiros anos, o acolhimento era para ajudá-los a "lidar com a morte" e a "morrer com dignidade". Paralelamente, as iniciativas mais politizadas, usavam a noção de proteção de direitos. Muitos depoimentos compararam as atividades de religiosos às de assistência integral à saúde, concebidas como "cuidado do corpo, da alma e da cidadania".

Sob a orientação, ou mais precisamente, "convocação à ação" dos profissionais que dirigiam os programas de Aids no final dos anos 1980, adeptos da matriz afro-brasileira e católicos organizaram as primeiras Casas de Apoio para crianças e adultos vivendo com Aids que, rejeitados pelas famílias, eram ali acolhidos. Grupos evangélicos com casas para internação de usuários de drogas estenderam seu trabalho para acolher doentes com esse perfil. Ou seja, os profissionais de saúde, adeptos ou não de alguma religião, começavam a se dedicar à prevenção e procuravam ativamente as lideranças religiosas para ampliar o alcance de seu trabalho. Articulou-se o "Grupo Religioso de Educação, Apoio e Solidariedade", definido como "grupo ecumênico", que reunia diferentes tradições religiosas para planejar a atuação e capacitação de integrantes das diversas religiões representadas. Em 1988 e 1989, o Centro de Referência e Treinamento de Aids de São Paulo reuniu, então, sacerdotes afro-brasileiros, luteranos, presbiterianos, católicos, judeus, mórmons e kardecistas em oficinas, palestras, na produção de cartilhas e materiais informativos com linguagem apropriada a cada matriz religiosa. Religiosos católicos e da matriz protestante - evangélica demoraram mais a se aproximar do tema da prevenção. 
Em síntese, a primeira década da resposta organizada pelo estado em colaboração com a sociedade civil, conseguiu validar o debate científico junto a religiosos e possibilitou a disseminação de informações corretas e a diminuição da discriminação das pessoas vivendo com HIV. A noção de solidariedade e a perspectiva da promoção de direitos, a exemplo de concretização da reforma da saúde no estado na direção da garantia da saúde integral para todos (universal), antes que o SUS começasse a existir de fato, tocaram a religiosidade dos que enfrentaram a epidemia de modo colaborativo com as autoridades de saúde. Esse discurso de enfrentamento religioso estimulava nos fiéis um enfrentamento de estilo colaborativo e não delegante.

Ao final da segunda década, a parceria mais íntima entre o Programa Estadual de DST/Aids e os grupos religiosos restringiu-se a iniciativas isoladas e bastante pontuais. Como discutiram Souza et al. (2012), apenas depois da pressão política dos adeptos de religiões de matriz afro-brasileiras e de uma nova geração dedicada à promoção da saúde da população negra no Brasil, em 2002 se organiza o Grupo de Trabalho Aids e Religiões (GT-Religiões). A noção de "inter-religiosidade", uma inovação técnica, substitui a noção de "ecumenismo" e redefine o espaço e as atividades aumentando a ênfase na prevenção. A presença católica - as atas e as atividades analisadas deixam claro - é bastante mais rara do que no início da epidemia. O trecho a seguir esclarecerá a produção dessa situação.

\section{A Resposta Católica em São Paulo: Pastoralistas vs Canonistas}

Vários entrevistados católicos citaram um número significativo de padres morrendo de Aids nos primeiros anos da epidemia, muitos vindos de outras regiões do país para São Paulo. Os números citados pelos entrevistados variam, mas estão sempre em torno de 50 religiosos com Aids. O sacerdote que viveu esse período, narra o primeiro caso.

Foi o primeiro padre que morreu de Aids aqui em São Paulo. Ele era professor antes de entrar para o seminário e foi internado no hospital. . . E eu posso falar dessa freira que deve ter acolhido mais de trinta casos, acompanhando, viu? . . Tem um sendo acompanhado até hoje, com 83 anos. E eu tive todo o cuidado de manter o contato normal, humano, amigo, fraterno... [Era] jovem! Chamou atenção, sobretudo do cardeal arcebispo e da Pastoral da Saúde da Arquidiocese. Foi internado num hospital público e a reação dos profissionais do hospital foi muito reservada, muito temerosa, de maneira que o padre não durou muito tempo, faleceu depressa, assim como acontecia com todos os casos da primeira etapa. E no velório muitas pessoas não se aproximaram do caixão, aliás, o caixão estava lacrado. Na hora de sair para o enterro o senhor da funerária se recusou a pegar na alça do caixão por medo de contágio. E a familia realmente estava profundamente chocada. Mas na Igreja foi acolhido, normalmente acompanhado. Este é o primeiro caso. (Padre ativo na Pastoral)

As autoridades católicas pastoralistas, como nomeou um dos entrevistados, preferiam a atuação colaborativa e "ecumênica", "em solidariedade" com todas as religiões na direção do "bem comum". Incentivavam a dedicação do "carisma" às ações sociais, organizavam Comunidades Eclesiais de Base (CEB), pastorais temáticas (do trabalho, da saúde, entre outras) para disseminar os princípios da participação na solidariedade. O enfrentamento colaborativo da emergente epidemia era uma das suas frentes.

Esse movimento não acontecia em todo lugar. A religiosidade das autoridades católicas mais conservadoras demorou para assumir a Aids como questão específica, definia o debate sobre a missão evangelizadora como o central. Como já discutiu Galvão (1997), tratavam da retomada da catequização para fazer frente à crescente atuação com base na Teologia da Libertação (TL) enquanto enfrentavam o crescimento dos grupos de matriz evangélica no país. Organizavam movimentos de renovação carismática para atrair fiéis com cantos efusivos, com rituais de impostação de mãos e uso da rádio e da televisão (canais de concessão estatal), até hoje inacessíveis a outras matrizes religiosas não cristãs. 
Os entrevistados comentaram com ênfase esse alinhamento do Arcebispo do Rio de Janeiro à posição oficial do Vaticano de João Paulo II. Como outros católicos mais canônicos que se manifestavam sobre a epidemia, incluindo muitos médicos, enfrentava-se o aparecimento da Aids nesse período como algo, no máximo, restrito ao universo da moral, ou da punição divina, adotando um discurso que poderíamos incluir no estilo de enfrentamento delegante.

Em outro extremo, estavam os adeptos da Teologia da Libertação (TL), a corrente que engloba diversas teologias cristãs surgidas na América Latina, como definiu um dos padres entrevistados. Como discutiu Perea (2004) muitos teólogos da libertação foram acusados de fomentar a formação de "células comunistas dentro da Igreja" porque organizaram as CEB com a lógica das primeiras comunidades de católicos, um modo de organização associado à inspiração socialista pelos seus opositores. Integrados na fé cristã, concentram-se na situação de pobreza e desigualdade social interpretada como produto de estruturas econômicas e sociais injustas e na teologia que "concebe as pessoas pobres e carentes não como um objeto de caridade, mas como sujeitos da libertação, solidária, de sua carência". Sua religiosidade é dedicada à mudança social e à missão pastoralista, que "implica estar junto com o povo pobre". Um entrevistado definiu a religiosidade dos canonistas como "ligada ao direito canônico da Igreja que resiste à renovação", uma preferência de governos politicamente conservadores da América Latina.

Esses dois extremos representavam, de um lado, a posição oficial do vaticano, canônica e hegemônica no Rio de Janeiro e, de outro, uma posição oficiosa que prevaleceu na relação semi-institucional de diversos setores da Igreja com a resposta governamental à Aids realizada em São Paulo (Murray, Garcia, Muñoz-Laboy, \& Parker, 2011). A resistência à posição mais canônica e oficial foi justificada, por vários entrevistados, também com base nas missões especiais de cada congregação, como no caso dos Camilianos - congregação dedicada aos doentes - que acolheram sacerdotes e seminaristas com Aids, ou atuaram junto aos doentes em capelanias de hospitais públicos. ${ }^{11}$

A congregação religiosa a que pertenço estabelece que os membros da Ordem devem estar dispostos a dar as suas vidas a assistir pessoas acometidas de moléstias infecciosas. [Era] minha postura face à nova doença logo que apareceu em São Paulo . . . entre os primeiros casos um padre infectado pelo HIV. (Padre camiliano)

Padres e agentes pastorais que trabalhavam com crianças e adultos moradores de rua, em contato com trabalhadores do sexo e usuários de drogas, ou nas favelas, agiam para disseminar informações sobre a doença e a prevenção nas suas ações sociais e paróquias. A maioria deles já tinha "presenciado o padecimento e isolamento" de pessoas morrendo de Aids. Muitos desses ativistas e voluntários entravam, ou invadiam mesmo, os gabinetes da secretaria da saúde exigindo "mais leitos" ou condições para fornecer cuidados paliativos e "dignidade" aos que adoeciam e morriam. ${ }^{12}$

Ligado ao contexto hospitalar, tentei a criação de uma unidade para assistência às crianças com HIV na clínica infantil. A diretoria da clínica se recusou terminantemente. Dizia-se que se fossem internadas crianças portadoras de HIV a população não internaria mais crianças na clínica. (Padre capelão)

11 Para os que não conhecem, a estrutura hierárquica da Igreja está centralizada no Papa que legisla por meio de documentos oficiais (como bulas, encíclicas) e dirige o colégio dos bispos que tem jurisdição sobre os fiéis do território de sua diocese, que inclui padres (párocos e vigários) com funções em determinados locais e paróquias. A arquidiocese é uma diocese importante, por motivos históricos ou tamanho. O modo de funcionar da estrutura, entretanto, permite a agregação de missões distintas. Por exemplo, congregações distintas (de camilianos, franciscanos, jesuítas) organizam a formação de religiosos em sua missão específica como atores da sociedade civil mais ampla. A missão das congregações excede, portanto, rituais compartilhados por todos os católicos (a missa aos domingos, o terço, as festas especiais, o batismo, a crisma, o casamento, a extrema-unção às vésperas da morte).

12 http://www.forumaidssp.org.br/publicacoes_ed2/ assistencia.htm (Acessado 20 de maio de 2009). 
Porque participavam da resistência democrática, as organizações eclesiais de base acumularam repertório político para compreender os princípios do Estado Laico consagrado ao final da década na Constituição. Segundo vários entrevistados, os católicos progressistas ativos nas diversas estruturas da Igreja, nas ONG ou no governo contribuíram, então, para ampliar o respeito à liberdade de crença e até de orientação sexual nos espaços de formulação de políticas públicas. Atores religiosos e governamentais concebiam a participação de modo semelhante: "como consulta e envolvimento no trabalho de base na mobilização e na proposição de ações locais e, ao mesmo tempo, aumentar a cidadania e promover a emancipação". Programas de Aids de diversos municípios também aceitavam o financiamento de organizações não governamentais com o orçamento público (Garcia \& Parker, 2011), com base no princípio da participação e da descentralização, prática que se mantém até a

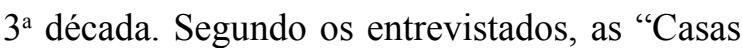
de Apoio" organizadas no período seguinte e as ONG dedicadas ao enfrentamento da epidemia, iniciativa de religiosos pastoralistas, surgiram "por necessidade". Num período em que o SUS ainda não existia e os hospitais de retaguarda demoraram a reagir adequadamente, a Pastoral da Saúde incentivava os voluntários a se mobilizarem "cada um do seu jeito", fortalecendo a autonomia. Um dos fundadores do Programa de Aids em São Paulo exemplificou:

Quando se apresentou o projeto de casas de apoio e as instituições candidatas houve muitas reações... "Mas perai, que é isso? Um pai de santo [coordenador casa de apoio], não é possível!..." Mas as autoridades [governamentais] terminaram concordando. A questão seguinte: como é que você vai passar dinheiro? E não foi a primeira discussão. Nós conseguimos em 88 o primeiro contrato formal de repasse de dinheiro do Estado de São Paulo. Muitas discussões com o setor jurídico, com o setor político, que achava um absurdo, fazer contrato com uma travesti (Brenda Lee) que tinha uma casa [de apoio] onde moravam profissionais do sexo. [Nesse contexto...]
A Igreja deveria ser vista como qualquer outra organização da sociedade civil com iniciativas para amparar, reduzir o impacto social e cobrir aquilo que o Estado não podia ou não tinha como prover. (médico sanitarista)

A colaboração do Estado com a Igreja Católica foi, desde então, fortemente baseada na noção de que "a igreja consegue chegar em vários lugares onde o poder público e até mesmo o privado não consegue, né?", como lembra um ativista da Pastoral da Aids entrevistado, argumento que se repetiu em outros estados do Brasil (Garcia, Muñoz-Laboy, \& Parker, 2011; Murray et al., 2011) Apoiadas diretamente pela Arquidiocese de São Paulo ou por missionários, casas de apoio foram abertas para adultos e crianças vivendo com HIV, especialmente as mais necessitadas "do ponto de vista sócio-econômico"13 - uma economia-política que interpretava a opressão e a solidariedade. Valorizada por entrevistados de todas as matrizes, a Arquidiocese de São Paulo deste período deixou como legado uma organização social sem fins lucrativos, muito atuante em defesa dos direitos das pessoas vivendo com HIV, acolhendo a seu modo todas as religiões. Vinte e cinco anos depois essa organização ainda desenvolvia ações no campo da saúde, da educação contra a discriminação sexual e de gênero, atendimento jurídico e distribuição de alimentação.

Muitos entrevistados contaram a história do Frei Franciscano que era portador do HIV e, ao assumir sua condição homossexual, fundou uma ONG.

O Frei queria algo mais técnico e cientifico. Ele queria um trabalho que valorizasse o portador do HIV/Aids como um ser humano, que não tivesse a morte como único caminho para a sua vida sofrida. A grande preocupação dele era não alimentar no soropositivo o estigma de ser um "morto social". Queria trazê-lo de volta à vida... O Centro surgiu numa época de pânico. Depois, houve um trabalho forte de educação,

13 http://www.alivi.org/Alivi/quemsomos.htm (Acessado 20 de maio de 2012). 
política . . . Num primeiro momento atuamos como representantes do portador de HIV. Mas, partir de um certo ponto . . O próprio portador deveria protagonizar a sua vida... seus direitos, ocupar os espaços que lhe cabem, que lhe é devido. (Profissional de saúde da ONG)

Criada e apoiada por franciscanos, a organização exerceu um papel importante na construção da resposta não governamental. Com o tempo, os trabalhadores desse centro exigiram a superação da benemerência, a criação de multiplicadores e protagonistas que ocupassem lugar junto ao poder público. Pode-se observar que, como nos serviços de saúde especializados em Aids, os usuários rejeitados e estigmatizados tratavam o espaço como uma extensão da casa deles, independente de seu credo pessoal. Uma assistente social insistiu em seu depoimento que religiosos começaram a dizer "Olha, não somos nós que temos que tomar conta da sua vida, mas é você que tem que dirigir sua vida e não a instituição".

O relatório Quinquenal (1985-1989) da Arquidiocese de São Paulo para o Vaticano, pela primeira vez se incluiu "a ação pastoral em resposta a Aids". Em um trecho pode ser lido o balanço que afirmava um projeto próprio da Igreja paulista:

Nos últimos anos, São Paulo se tornou um centro de doentes de Aids da América Latina. A igreja de São Paulo não se omitiu neste campo. Desenvolveu amplo trabalho de conscientização da população sobe a gravidade da moléstia, suas vias de transmissão e como evitar a sua difusão. Promoveu e participou de debates e dias de estudos em vários níveis, inclusive de caráter ecumênico. Os párocos e as demais instituições eclesiais foram estimulados a dar a sua colaboração (Arquidiocese de São Paulo, 1990, p. 103).

Foi nesse período histórico que a TL foi condenada duas vezes pelo então Cardeal Joseph Ratzinger ${ }^{14}$, prefeito da Congregação para a Doutrina da Fé. Em 1989, a ação papal reduziu o território da Arquidiocese de São Paulo dividindo-a em quatro novas dioceses. Os entrevistados

14 Depois Papa Bento XVI. foram unânimes em afirmar que a postura de D. Paulo e sua "igreja de base" frente à epidemia da Aids foi uma gota d'água para a decisão de dividir a diocese sob sua responsabilidade. As organizações sociais religiosas e a igreja de base lideravam um movimento de transformação da religiosidade, em rede com outras organizações com quem aprendiam a compreender e a enfrentar a epidemia.

Foi quando o debate sobre a prevenção e o uso do preservativo começou a tomar corpo e o Vaticano ampliou sua ação política no campo da Aids. A cena presenciada pelo padre octagenário é marcante:

Não me lembro o ano... no primeiro congresso sobre a Aids feito no Vaticano um padre africano com Aids estava lá, e o cardeal que presidia mandou retirá-lo da sala. Depois houve uma reação [contra a expulsão] e ele mandou chamar. Naquele mesmo congresso, o hoje cardeal [X] falou que se num casal um tivesse Aids e se quisesse manter relação sexual, que um dos dois se dispusesse a pegar Aids mas que não usasse a camisinha. (Padre ativo na Pastoral)

Enquanto religiosos, gestores de programas e estados continuavam negando a prioridade e emergência da epidemia, produzindo um discurso de enfrentamento delegante ou moralista, aumentava a vulnerabilidade programática dos socialmente mais vulneráveis. A linha mais canonista entrou forte no debate sobre prevenção.

\section{As Controvérsias sobre o Preservativo: "Fura Menos que os Furos na Monogamia e Fidelidade de Casais"}

Contexto mais raro em outros países, a articulação entre governo e sociedade civil na primeira década da epidemia incluiu diversas organizações da Igreja Católica que reconheciam a contribuição da ciência e dos referenciais ético-políticos da reforma sanitária. Muitos entrevistados se referiam às iniciativas da CNBB da época como uma posição oficiosa mais favorável ao preservativo. Um dos organizadores do programa de Aids descreveu assim essas posições: 
A primeira vez que eu ouvi [membros da Igreja] recomendando o preservativo, eram pessoas trabalhando com meninos de rua. Em 88, 89, no programa [de TV estava] Dom Paulo. Como combinado, o apresentador perguntava "quais eram as recomendações para a prevenção, o que é que se devia fazer, incluir informação, etc, e o uso do preservativo, tal, não é?" Dom Paulo não usou a palavra preservativo: "Nós temos que apoiar... barará barará. A Igreja está orientada a apoiar as autoridades sanitárias na forma como foi apresentada pelo Dr. Paulo Teixeira" [do Programa de Aids]... Acho que 92, a Pastoral da Juventude, por decisão da CNBB, adotou a Aids como questão a ser tratada junto às comunidades de jovens. Na época, nós nem tínhamos qualquer possibilidade de apoiar financeiramente, então ficou uma parceria muito mais de caráter político. (Médico sanitarista)

Padres e bispos em outros estados, enquanto isso, reforçavam sua posição canônica e enfatizavam o pecado da homossexualidade, o valor da monogamia e do compromisso conjugal, pregando a abstinência e a fidelidade como melhor caminho para evitar a Aids. Sem o apoio de D. Paulo, o conflito ficou mais aberto.

Citado por muitos entrevistados, foi emblemática a controvérsia em torno da punição do Padre Valeriano que anunciou a produção de um vídeo questionando o posicionamento do Vaticano que era irredutivelmente contrário aos preservativos. Foi punido porque, em entrevista a um jornal diário, defendeu o uso e a distribuição de preservativos. ${ }^{15}$ Diversos entrevistados lembraram que Dom Eugênio Sales (RJ) produziu nota de repúdio assinada também por Dom Hummes, novo cardeal-arcebispo de São Paulo, reação interpretada como intervenção direta do Vaticano e dos seus "representantes e espiões no Brasil". Contaram que na Conferência dos Bispos convidou-se "alguém de Roma" para falar

15 Essa polêmica repercutiu na imprensa brasileira e estrangeira, como ilustrado nas reportagens: Cafardo (2000), "Is Prete Difende" (2000), Jordan (2001) e "Religioso diz que CNBB" (2000). sobre como a Igreja estava enfrentando a Aids mundialmente. Nas palavras de um padre missionário:

Veio não somente para isso: ele veio fiscalizar uma igreja do Brasil que estava transmitindo o uso do preservativo. O cardeal de Rio de Janeiro, que nós chamamos de mafioso da igreja católica no Brasil, reportava tudo que acontecia aqui à Roma. Então preparamos esse panfleto, o bispo estava junto conosco e levou para a diretoria da CNBB para ver se eles aprovavam. Eles aprovaram, imprimiu-se. Quando veio o enviado de Roma, mandou retirar o panfleto e pediu que a CNBB se retratasse, porque nós falamos: "isso foi aprovado pela CNBB". $A C N B B$ falou que nunca tinham visto o material e o bispo, que acompanhava esse trabalho, ficou do lado da CNBB. Foi um desastre. (Padre missionário)

Ativistas de ONG foram, então, fazer uma manifestação na porta da casa do arcebispo que aceitou uma comissão, "e morreu tudo por ai", conta um entrevistado. A comissão que trabalhava junto a CNBB foi desfeita e substituída " $n a$ surdina por outra comissão vaticanista." A posição pública, entretanto, era menos clara: "Roma não quer perder o diálogo com os governos" segundo um padre entrevistado que explicou que a Igreja temia a reação do debate aberto na mídia e preferia não ampliar a controvérsia.

Em 2003, em uma carta aberta ao Programa Nacional de DST/Aids do Ministério da Saúde, a presidência da CNBB defende as iniciativas da Igreja no apoio e cuidado dos doentes, na prevenção e superação do preconceito de afetados pela epidemia e divulga sua perspectiva sobre a sexualidade. Oferece sua interpretação alternativa ao pensamento técnico-científico apenas quanto ao modo de abordar a prevenção. Questiona a eficácia do preservativo e, lembrando a existência de outros "métodos eficazes", defende uma ordem moral e dogmática para a formação da juventude, uma "antropologia da sexualidade" que teme a educação sexual compreensiva e completa que estimularia o comportamento sexual sem limite e irresponsável (CNBB, 2003).

A partir desse momento, várias autoridades eclesiásticas passaram a estimular controvérsias 
públicas sobre a eficácia do preservativo e a propagar que o preservativo "fura". Um sacerdote entrevistado comentou: "fura menos que os furos na monogamia e fidelidade dos casais". Apesar de tudo, a resposta oficiosa da Igreja de base seguiu em São Paulo, defendendo "o evangelho do bom samaritano", como comentou um agente da Pastoral entrevistado insistindo que é papel

de todo cristão, de todo ser humano dar a informação correta e falar de tudo sobre Aids. Tudo! O padre não está ali, o bispo não está ali. Entendeu? A nivel local continuaram o trabalho: "de esclarecimento, de exigir politicas que favoreçam essa formação, esse conhecimento e possam ajudar as pessoas e, sobretudo a juventude a se preservar, a se precaver". (Padre de paróquia)

O Programa Nacional de DST/Aids, que desde os anos 1990 caminhou em sintonia com a resposta paulista (Berkman et al., 2005; Teixeira, 1997, 2003) entrou forte no debate. A reação mais emblemática foi a "Campanha Pela camisinha não passa nada", cuja imagem central mostrava um preservativo transformado em aquário para peixes nadando, sintetizando a mensagem "Use e confie". ${ }^{16}$ Disseminavam-se informações e orientação sobre a segurança do preservativo e a maneira correta de usá-lo consistentemente.

\section{Lições da Resposta à Aids sobre o Enfrentamento Religioso}

A contribuição de religiosos paulistas para a bem sucedida resposta social à Aids não pode ser ignorada ou minimizada. A história aqui relatada é a versão dos participantes dessa resposta articulada com aos programas governamentais, um limite deste estudo. De todo modo, a dinâmica da religiosidade e do enfrentamento religioso pôde ser descrita também na perspectiva das autoridades religiosas, um enfrentamento visivelmente atravessado pela dimensão institucional e política, compreensível apenas se ampliado

16 Pode-se assisti-la no site: http://www.aids.gov. br/campanha/carnaval-2004-pela-camisinhanao-passa-nada-use-e-confie (Acessado em maio de 2012) da dimensão individual e estritamente comportamental. Em outras palavras, observou-se neste estudo a marca do político na religiosidade e no estilo de enfrentamento adotado, pessoal e institucionalmente, que é disseminado entre fiéis e adeptos.

Em síntese, desde os anos 1980 adeptos de várias religiões contribuíram em São Paulo com programas governamentais dedicados a garantir o acesso e o direito à saúde integral de portadores e a prevenção centrada no preservativo, como parte da sociedade civil. Esse movimento social foi significativo, como discutiu Correa (1997): sempre coube à sociedade civil a denúncia do descaso governamental, a sustentabilidade da proteção da cidadania das pessoas vivendo com HIV e o debate público sobre a importância da solidariedade.

A seu modo, os religiosos que participaram deste estudo contribuíram para superar a negação (denial) da emergência da epidemia desde a primeira década, quando a Aids atingia com maior prevalência homens homossexuais e usuários de drogas. Integraram o que aprendiam ao discurso religioso tradicional e à sua religiosidade pessoal, transformando-a diante da inesperada situação. Ao fazê-lo, como vimos, interpelaram a religiosidade institucional e um estilo de enfrentamento que estimulava a negação e a discriminação de doentes, como o caso dos católicos em São Paulo que viveram um acirrado debate interno, sofreram o isolamento ou a punição pela alta hierarquia alinhada com o Vaticano. O compromisso de católicos humanistas com diversos movimentos sociais, em sinergia com cristãos de várias denominações inspirados pela Teologia da Libertação, construiu um estilo de enfrentamento religioso necessariamente colaborativo que foi produtivo para responder à situação crítica e à emergência da epidemia. Distanciaram-se do discurso da maior parte dos religiosos cristãos, de cientistas e profissionais que também reagiam com base em sua religiosidade e moral desconsiderando evidências científicas acumuladas. ${ }^{17}$

17 Desconsideravam até estudos epidemiológicos irrefutáveis sobre os modos de transmissão do vírus isolado 
Estes religiosos promoviam um estilo delegante de enfrentamento: Deus puniria os promíscuos com a Aids e salvaria da pandemia os adeptos da moralidade proposta nos livros sagrados. O "mau comportamento" produziria a infecção e o adoecimento.

Muitos católicos que, durante os primeiros anos da epidemia, equacionaram o debate interno católico, permaneceram por mais de duas décadas assessorando a chamada "igreja de base" e também os programas governamentais de Aids. Outros reconstruíram "sua missão" depois que se puniu dissidentes mantendo-se distantes do discurso oficial e institucional de enfrentamento. Como notou Perea (2004), porque se reconheciam com direito de falar como indivíduos na construção de espaços cotidianos e exercer sua liberdade de consciência.

\section{Como a Vulnerabilidade ao Adoecimento, o Enfrentamento Religioso tem uma Dimensão Pessoal, Institucional e Sócio-Política}

A literatura sobre enfrentamento reconhece a influência da cultura e seu poder de modelar avaliações de situação, os sistemas de orientação das pessoas no mundo, assim como o poder de privilegiar quais estratégias de enfrentamento se deve ensinar (Faria \& Seidl, 2005). Os dados desta pesquisa certamente confirmaram essa concepção que, infelizmente, não tem sido o foco da maior parte dos estudos sobre enfrentamento religioso. Referenciado na perspectiva dos direitos humanos e na psicologia social na saúde que chamamos de construcionista social (V. Paiva, 2012a, 2012b), este artigo se propôs a expandir este foco e ressaltar as dimensões políticas e institucionais que contextualizam o enfrentamento religioso.

Como os estudiosos das religiões, este estudo também observou como brasileiros negociam fortemente com a regulação dogmática (Duarte, 2005; Duarte, Gomes, Jabor, \& Luna, 2006; Garcia et al., 2009; Martins, 2009). Ou seja, convicções religiosas participam das decisões no âmbito privado com razoável autonomia frente os ditames doutrinários. Diferentes cosmovisões implicadas em crenças e rituais não explicam, portanto, o comportamento cotidiano dos frequentadores dos cultos, como já discutimos antes (V. Paiva, Garcia, Santos, Terto, \& Munoz-Laboy, 2010).

Se o fenômeno tem sido observado entre fiéis e adeptos, este recorte da história do enfrentamento religioso da epidemia da Aids nos permitiu observar que ocorre também entre autoridades religiosas, clérigos e sacerdotes que, por sua vez, produzirão os discursos públicos de enfrentamento que estarão disponiveis para os adeptos de cada grupo religioso.

Neste processo, o "sujeito religioso" que é protagonista de sua religiosidade pessoal e ator histórico, recria o discurso oficial da autoridade maior, para torná-la congruente com sua experiência, como já tinha observado Watanabe (2005) entre fiéis protestantes e Silva, Santos, Carli e Paiva (2008) observaram entre jovens de diversas religiões. As escolhas de cada autoridade religiosa (padre, educadores, reverendos, pastores, diaconisas, pais e mães-de-santo) expressam suas dinâmicas cognitivas e emocionais, discutidas na literatura sobre enfrentamento religioso, ao mesmo tempo em que expressam e produzem os simbolismos derivados de processos sociais e políticos. A religiosidade desses clérigos e religiosos ativos em suas comunidades que foram atores-chaves na construção da resposta à Aids em São Paulo, como vimos, foi marcada pelo contexto sócio-político onde também se fortalecia a perspectiva humanista e dos Direitos Humanos nos programas governamentais de saúde aliados à sociedade civil organizada.

Não há, portanto, resposta simples à pergunta de Defert (1996) incluídas na introdução: profissionais devem temer a intervenção religiosa ou considerá-la aliada? A lição que se pode aprender desse processo histórico: profissionais devem prestar atenção à religião viva do cotidiano das pessoas, ou seja, à religiosidade que será intersubjetivamente mobilizada a cada contexto social e institucional (comunitário, programático, local, nacional, internacional). Considerar a religiosidade de adeptos e fiéis nas comunidades, nas escolas e locais de trabalho onde promovem saúde ou assistência social é tão importante quanto a religiosidade viva das autoridades religiosas e dos clérigos de cada matriz - não apenas seu discurso sobre princípios. 
Embora muitas autoridades religiosas tenham a obrigação de representar a tradição e o dogma, frequentemente a interpelação direta dos dogmas por agentes governamentais produz um debate que costuma não ir adiante, especialmente quando a sexualidade está envolvida. Dificulta ou mesmo paralisa gestores com a responsabilidade de promover e proteger o direito a saúde dos cidadãos de um estado laico.

A religião viva, a que se realiza nas cenas singulares da vida cotidiana de cada pessoa, referida ao cenário cultural e político local, tem sido uma porta de entrada mais relevante. Permite a interação com usuários, profissionais de saúde, e autoridades religiosas cuja religiosidade também é fruto de interações cotidianas e intersubjetivas (V. Paiva et al., 2010). Como o sacerdote entrevistado insiste:

Digo sempre: "eu fiz o voto de castidade, faz 28 anos que sou padre, mas se eu não renovar todos os dias a minha escolha de valores evangélicos (a castidade, a pobreza e assim por diante), o mundo me engole vivo". Porque esses valores não dependem unicamente da pessoa, mas esta pessoa vive dentro do mundo, de uma sociedade, e o que para nós são valores evangélicos, para a sociedade não são valores. Para a sociedade, ela diz: "eu transar com um, dois, ou mil, tanto faz; eu me sentir bem, satisfeito, e pronto". Então devemos levar à frente os discursos desses valores com os pés no chão. E não pensar que o homem, só porque foi batizado, vira santo. Ou não pensar que no dia que fui ordenado padre, viro anjo. (Padre missionário)

Com paralelos em matrizes religiosas menos centralizadas, deve-se distinguir, portanto, "a resposta católica" da "resposta da Igreja Católica". Perea (2004) inclui na primeira os atores da sociedade que significam/resignificam o catolicismo alinhados aos direitos humanos nos diversos aspectos da vida em que eles se apresentam; a segunda estaria implicada nas normas criadas e sistematizadas por meio de instâncias burocráticas, que os participantes deste estudo chamaram de "canônicos". Padres, arcebispos e capelães que atuam com base em interpretações mais abertas ao debate sobre direitos, em espe- cial dos direitos sexuais e reprodutivos, podem trazer contribuições significativas especialmente quando a Igreja mesma aceita-se atingida pela Aids (Transferetti, 2001, 2005).

Em outros contextos, e diferente de outros países que não enfrentaram ditaduras e o debate sobre uma reforma sanitária nem assistiram a produção de uma teologia autóctone como a Teologia da Libertação, nas "respostas católicas" brasileiras (no plural) o enfrentamento associou-se também à visão política de cada missão religiosa. (Seffner, Garcia, Muñoz-Laboy, \& Parker, 2011). Discursos e práticas de uma religiosidade mais canonista que estimularam um modo de enfrentamento delegante sustentaram a discriminação de pessoas afetadas pela epidemia da Aids e ampliaram, portanto, a vulnerabilidade social e individual ao adoecimento. Por exemplo, a vulnerabilidade à infecção de mulheres casadas aumenta, assim como a de seus filhos, quando permanecem sem se questionar sobre a monogamia e da fidelidade de seus maridos, entre outros princípios que aprendem na sua educação religiosa.

Toda vez perguntam: você é a favor ou contra o uso da camisinha? Existem duas éticas: uma de principio, uma de responsabilidade. A ética de principio diz que você não deve andar na rua contra mão de carro. Mas vamos supor que num momento de distração você não viu a placa, não percebeu e estava distraído e você entrou, aí você tem a ética de responsabilidade, toma cuidado pra não amassar o carro de ninguém, para não atropelar ninguém, assim se aplica a questão da camisinha. (Ativista da Igreja de base que promove o preservativo)

A pesquisa psicossocial no campo do enfrentamento religioso se enriqueceria, portanto, ao tratar de dimensão tão dinâmica da vida como a sexualidade e a religiosidade entendendo que não podem ser reduzidas ao comportamento individual nem serem relacionadas diretamente com o dogma, o sagrado e o transcendental. Religiosos em qualquer posição - de fiéis ou de autoridades religiosas - são pessoas implicadas em um contexto sócio-político e cultural. Uma psicologia social da religião que reconheça mais fortemente a construção histórica dos discursos 
que produzem o universo simbólico compartilhado e os sentidos das dimensões emocionais e cognitivas do enfrentamento e de seus estilos, pensará a religiosidade e o enfrentamento religioso nas dimensões ao mesmo tempo pessoais e institucionais e inextricavelmente atravessadas pelo contexto cultural e político. Como no caso dos que participaram das primeiras respostas à Aids nos ensinaram, essa perspectiva pode ser mais produtiva para informar a atuação técnica do psicólogo.

\section{Referências}

Arquidiocese de São Paulo. (1990). Relatório Quinquenal 1985-1989: Vol. 6. São Paulo, SP: Autor.

Ayres, J. R. C. M., Paiva, V., \& França, I., Jr. (2010). From natural history of disease to vulnerability: Changing concepts and practices in contemporary public health. In R. Parker \& M. Sommer (Eds.), Routledge Handbook in Global Public Health (pp. 98-107). London: Routledge.

Ayres, J. R. C. M., Paiva, V., \& França, I., Jr. (2012). Conceitos e práticas de prevenção: Da história natural da doença ao quadro de vulnerabilidade e direitos humanos. In V. Paiva, J. R. Ayres, \& C. M. Buchalla (Orgs.), Vulnerabilidade e direitos humanos - Prevenção e promoção da saúde: Livro I. Da doença à cidadania (pp. 71-94). Curitiba, PR: Juruá.

Azevedo, D. (2004). A Igreja Católica e seu Papel Político no Brasil. Estudos Avançados, 18(54), 109-120.

Berkman, A., Garcia, J., Munoz-Laboy, M., Paiva, V., \& Parker, R. (2005). A critical analysis of the Brazilian response to HIV/AIDS: Lessons learned for controlling and mitigating the epidemic in developing countries. American Journal of Public Health, 95(7), 1162-1172.

Burawoy, M. (2009). The Extended Case Method: Four countries, four decades, four great transformations, and one theoretical tradition. London: University of California Press.

Burdick, J. (1996). Looking for God in Brazil: The progressive Catholic Church in urban Brazil's religious arena. Berkeley, CA: University of California Press.

Cafardo, R. (2000, 7 jul.). Ato em SP apóia padre pró-camisinha. Estadão. Recuperado em 7 de julho de 2000, de http://www.estadao.com.br/agestado/nacional/2000/jul/07/276.htm
Centro de Referência Técnica em Psicologia e Políticas Públicas. (2008). Referências técnicas para a atuação do(a) psicólogo(a) nos Programas de DST e AIDS. Brasília, DF: Conselho Federal de Psicologia.

Centro de Referência Técnica em Psicologia e Políticas Públicas. (2009). Práticas Emergentes e Inovadoras de psicólogos(as) no campo das DST/ AIDS: Vol. 1. Práticas em Psicologia e Políticas Públicas. Brasília, DF: Conselho Federal de Psicologia.

Chesnut, R. A. (1997). Born again in Brazil: The Pentecostal boom and the pathogens of poverty. Piscataway, NJ: Rutgers University Press.

Coates, T., Temoshok, L., \& Mandel, J. (1984). Psychosocial research is essential to understanding and treating AIDS. American Psychologist, 39, 1309-1314.

Conferência Nacional dos Bispos do Brasil. (2003, 09 dez.). Declaração da Presidência da CNBB sobre a "Carta aberta" do Programa Nacional de DST e Aids, do Ministério da Saúde. Recuperado em 22 de abril, 2013, de http://www.zenit. org/pt/articles/declaracao-do-episcopado-brasileiro-sobre-carta-aberta-do-programa-nacional-de-dst-e-aids

Correa, S. (1997). A solidariedade como solução. Boletim da ABIA - Associação Brasileira Interdisciplinar de AIDS, 37.

Defert, D. (1996). AIDS as a challenge to religion. In J. Mann \& D. J. M. Tarantola (Eds.), Aids in the world II (pp. 447-452). New York: Oxford University Press.

Duarte, L. F. D. (2005). Ethos privado e justificação religiosa: Negociações da reprodução na sociedade brasileira. In M. L. Heilborn, L. F. D. Duarte, C. Peixoto, \& M. L. Barros (Orgs.), Sexualidade, família e ethos religioso (pp. 137-176) Rio de Janeiro, RJ: Garamond Universitária.

Duarte, L. F. D., Gomes, E. C., Jabor, J., \& Luna, N. (2006). Família, reprodução e ethos religioso: Subjetivismo e naturalismo como valores estruturantes. In L. F. D. Duarte, M. L. Heilborn, M. L. Barros, \& C. Peixoto (Orgs.), Família e religião, (pp. 15-25). Rio de Janeiro, RJ: Contra Capa.

Faria, J. B., \& Siedl, E. M. F. (2005). Religiosidade e enfrentamento em contextos de saúde e doença. Revisão de literatura. Psicologia: Reflexão e Critica, 18(3), 381-389.

Farmer, P. (1999). Pathologies of power: Rethinking health and human rights. American Journal of Public Health, 89, 1486-1496. 
Galvão, J. (1997). As respostas religiosas frente à epidemia de HIV/AIDS no Brasil. In R. Parker (Org.), Políticas, instituições e aids: Enfrentando a epidemia no Brasil (pp. 109-134). Rio de janeiro, RJ: Jorge Zahar.

Garcia, J., Muñoz-Laboy, M., Almeida, V. de, \& Parker, R. (2009). Local impacts of religious discourses on rights to express same-sex sexual desires in periurban Rio de Janeiro. Sexuality Research and Social Policy, 6(3), 44-60.

Garcia, J., Muñoz-Laboy, M., \& Parker, R. (2011). Vulnerable salvation: Evangelical Protestant leaders and institutions, drug use and HIV and AIDS in the urban periphery of Rio de Janeiro. Global Public Health, 6(Suppl. 2), S243-S256.

Garcia, J., \& Parker, R. G. (2011). Resource mobilization for health advocacy: Afro-Brazilian religious organizations and HIV prevention and control. Social Science \& Medicine, 72(12), 1930-1938.

Garrido, P. B., Paiva, V., Nascimento, V., Souza, J. B., \& Santos, N. (2007). Aids, estigma e desemprego: Implicações para os serviços de saúde. Revista de Saúde Pública, 41(Supl. 1), 72-79.

Gaspari, E. (2002). A ditadura escancarada. São Paulo, SP: Cia das Letras.

Gough, B. (2007). Coming out in the heterosexist world of sport: A qualitative analysis of web postings by Gay athletes. Journal of Gay and Lesbian Psychotherapy, 11(1-2), 153-174.

Govender, K. (2011). The cool, the bad, the ugly, and the powerful: Identity struggles in schoolboy peer culture. Culture, health \& Sexuality, 13(8), $887-901$

Gruskin, S., \& Tarantola, D. (2008). Health and human rights: Overview. In K. Heggenhougen \& S. Quah (Eds.), International Encyclopedia of Public Health (Vol. 3, pp. 137-146). San Diego, CA: Elsevier.

Gruskin, S., \& Tarantola, D. (2012). Um panorama sobre saúde e direitos humanos. In V. Paiva, J. R. Ayres, \& C. M. Buchalla (Orgs.), Vulnerabilidade e Direitos Humanos. Prevenção e Promoção da Saúde: Vol. 1. Da doença à cidadania (pp. 23-42). Curitiba, PR: Juruá.

Is prete difende $\mathrm{i}$ preservativi la chies alo punisce. (2000, 5 di luglio). CNN Italia. Retrieved September 12, 2000, from http://www.cnnitalia. it/2000/MONDO/amerlatina/07/04/prete/

Jordan, M. (2001, February 21). Brazil's unconventional AIDS fight. The Wall Street Journal, p. I-IV.
Kian, E. M., \& Anderson, E. (2009). John Amaechi: Changing the way sport reporters examine Gay athletes. Journal of Homosexuality, 56(7), 799818. doi: 10.1080/00918360903187788

Mann, J., \& Tarantola, D. J. M. (Eds.). (1996). Aids in the world II. New York: Oxford University Press.

Martins, A. D. (2009). Catolicismo contemporâneo: Tratando da diversidade. In E. C. Gomes (Org.), Dinâmicas contemporâneas de fenômeno religioso na sociedade brasileira (pp. 125-146). Aparecida, SP: Ideias e Letras.

Mott, L. (1985). Aids: Reflexão sobre sodomia. Comunicações do ISER, 17, 32-41.

Murray, L. R., Garcia, J., Muñoz-Laboy, M., \& Parker, R. G. (2011). Strange bedfellows: The Catholic Church and Brazilian National AIDS Program in the response to HIV/AIDS in Brazil. Social Science \& Medicine, 72(6), 945-952.

Paiva, G. J. (1998). AIDS, Psicologia e religião: O estado da questão na literatura psicológica. $P s i$ cologia: Teoria e Pesquisa, 14(1), 27-34.

Paiva, G. J., Zangari,W., Verdade, M. M., Machado de Paula, J. R., Faria, D. G. R., Gomes, D. M., ...Gomes, A. M. A. (2009, jul./set.). A Psicologia da Religião no Brasil. Psicologia: Teoria e Pesquisa, 25(3), 441-446.

Paiva, V. (2008). A psicologia redescobrirá a sexualidade? Psicologia em Estudo, 13, 641-651.

Paiva, V. (2012a). A dimensão psicossocial do cuidado. . In V. Paiva, J. R. Ayres, \& C. M. Buchalla (Orgs.), Vulnerabilidade e Direitos Humanos. Prevenção e Promoção da Saúde: Vol. 2. Entre indivíduos e comunidade (2. ed., pp. 41-72). Curitiba, PE: Juruá.

Paiva, V. (2012b). Cenas da vida cotidiana: metodologia para compreender e reduzir a vulnerabilidade na perspectiva dos direitos humanos. In V. Paiva, J. R. Ayres, \& C. M. Buchalla (Orgs.), Vulnerabilidade e Direitos Humanos. Prevenção e Promoção da Saúde: Vol. 1. Da doença à cidadania (pp. 23-42). Curitiba, PR: Juruá.

Paiva, V., Aranha, F., Bastos, F. I. P. M., \& Grupo de Estudos em População, Sexualidade e Aids. (2008). Opiniões e atitudes em relação à sexualidade: Pesquisa nacional brasileira. Revista de Saúde Pública, 42, 54-64.

Paiva, V., Garcia, J., Santos, A. De O., Terto, V., Jr., \& Munoz-Laboy, M. (2010). Religious communities and HIV prevention: An intervention-study using human rights based approach. Global Public Health, 5, 280-294. 
Paiva, V., \& Zucchi, E. (2012). Estigma, discriminação e saúde: Aprendizado de conceitos e práticas no contexto da epidemia de HIV/Aids. In V. Paiva, J. R. Ayres, \& C. M. Buchalla (Orgs.), Vulnerabilidade e Direitos Humanos. Prevenção e Promoção da Saúde: Vol. 1. Da doença a cidadania (pp. 111-144). Curitiba, PR: Juruá.

Parker, R., \& Aggleton, P. (2001). Estigma, discriminação e AIDS: Vol. 1. Coleção Cidadania e direitos. Rio de Janeiro, RJ: Associação Brasileira Interdisciplinar de AIDS.

Parker, R., \& Aggleton, P. (2003). HIV and AIDS related stigma and discrimination: A conceptual framework and implications for action. Social Science \& Medicine, 57, 13-24.

Parker, R., Garcia, J., \& Muñoz-Laboy, M. (2013). Sexual Social Movements and Communities. In D. L. Tolman \& L. Diamond (Eds.), The American Psychological Association's Handbook of Sexuality and Psychology. Washington, DC: American Psychological Association.

Perea, J. G. F. (2004). Tres reflexiones sobre la sexualidad y los derechos humanos en el ámbito de la Iglesia católica. Estudios Demográficos y Urbanos, 57, 639-686.

Peres, J. F. P., Simão, M. J. P., \& Noasello, A. G. (2007). Espiritualidade, religiosidade e psicoterapia. Revista de Psiquiatria Clínica, 34(Suppl. 1), 136-145. Recuperado em 27 de março de 2012, de SciELO.

Perucchi, J., Rodrigues, F. D., Jardim, L. N., \& Calais, L. B. (2011). Psicologia e Políticas Públicas em HIV/AIDS: Algumas reflexões. Psicologia \& Sociedade, 23, 72-80.

Pollozi, L., \& Souza, C. A. M. (Orgs.). (2001). Franco Montoro, humanismo e política. São Paulo, SP: Edições Loyola.

Religioso diz que CNBB só condena preservativo por pressão da Santa Sé. (2000, 26 jun.). Folha de São Paulo.

Sampaio, J., \& Araújo, J. L., Jr. (2006). A relevância dos aspectos sócio-culturais para as políticas públicas de prevenção em AIDS. Psicologia Política, 6(11), 83-106.

Sanchez, Z. V. D. M., \& Nappo, S. A. (2008). Religious treatments for drug addiction: An exploratory study in Brazil. Social Science \& Medicine, 67, 638-646.

Seffner, F., Garcia, J., Muñoz-Laboy, M., \& Parker, R. (2011). A time for dogma, a time for the Bi- ble, a time for condoms: Building a Catholic theology of prevention in the face of public health policies at Casa Fonte Colombo in Porto Alegre, Brazil. Global public health, 6(sup2), S271-S283.

Silva, C. G., Santos, A. O., Carli, D., \& Paiva, V. (2008, out./dez.). Religiosidade, juventude e sexualidade: Entre a autonomia e a rigidez. Psicologia em Estudo, 13(4), 683-692

Souza, P. O., Santos, N., Almeida, V., \& Paiva, V. (2012). O trabalho colaborativo com comunidades religiosas para a prevenção do HIV/Aids: A experiência do GT-Religiões em São Paulo. In V. Paiva, J. R. Ayres, \& C. M. Buchalla (Orgs.), Vulnerabilidade e Direitos Humanos: Vol. 1. Prevenção e Promoção da Saúde (pp. 239-271). Curitiba, PR: Juruá.

Teixeira, P. R. (1997). Políticas públicas em AIDS. In R. Parker, Politicas, instituições e AIDS: Enfrentando a epidemia no Brasil. Rio de janeiro, RJ: Associação Brasileira Interdisciplinar de AIDS.

Teixeira, P. R. (2003). Universal access to AIDS medicines: The Brazilian experience. Divulgação em Saúde para Debate, 27, 184-191.

Transferetti, J. (2001). Pastoral da Família e AIDS: Comunicação, saúde e conscientização. São Paulo, SP: Átomo.

Transferetti, J. (2005). CNBB, AIDS e Governo: Tarefas para uma teologia da prevenção. Campinas, SP: Átomo.

Vasconcellos, E. G. (1992). Aids e a morte psicossomática. In V. S. F. Paiva \& L. B. N. Alonso Fernandes (Orgs.), Em tempos da AIDS (pp. 32-37). São Paulo, SP: Summus.

Watanabe, T. H. B. (2005). Caminhos e histórias: A historiografia do protestantismo na Igreja Presbiteriana do Brasil. Revista de Estudos da Religião, 1, 15-30.

Zurba, M. C. (2011). Contribuições da Psicologia Social para o psicólogo na saúde coletiva. Psicologia \& Sociedade, 23, 5-11. 